\title{
Sedimentary profiles of Fe, Mn, V, Cr, As and Mo as indicators of benthic redox conditions in Baldeggersee
}

\author{
Tobias Schaller ${ }^{1}$, H. Christoph Moor ${ }^{2}$ and Bernhard Wehrli ${ }^{1}$ \\ ${ }^{1}$ Limnological Research Center, Swiss Federal Institute for Environmental Sciences \\ and Technology (EAWAG) and Swiss Federal Institute of Technology (ETH), \\ CH-6047 Kastanienbaum, Switzerland \\ 2 Swiss Federal Laboratories for Materials Testing and Research (EMPA) \\ CH-8600 Dübendorf, Switzerland
}

Key words: Lake sediments, redox indicators, trace metals, iron, manganese.

\begin{abstract}
Concentration profiles of $\mathrm{Mg}, \mathrm{K}, \mathrm{La}, \mathrm{Fe}, \mathrm{Mn}, \mathrm{V}, \mathrm{Cr}$, As and Mo were determined in samples from a freeze core taken at the deepest site of Baldeggersee in 1993. The special coring technique allowed an exact dating of the sediment samples and an annual resolution of the profiles. Long term changes in benthic redox conditions produce diagnostic trends in several metal profiles. $\mathrm{Fe}$, As and Mn enrichments trace the onset of anoxia at the deepest site of the lake. High values of Mo concentrations and $\mathrm{Cr} / \mathrm{V}$ ratios indicate periods of stable anoxic conditions in a meromictic hypolimnion. A comparison of oxygen time series with metal profiles between 1950 and 1990 indicates that $\mathrm{Mn}$ reacts sensitively to large seasonal variations of deep-water oxygen concentrations.
\end{abstract}

\section{Introduction}

The fate of trace metals in lakes is governed by numerous physical and biogeochemical processes. The relative importance of these processes depends on the geochemical conditions of the lake and on the chemical characteristics of each metal. The redox conditions in the deep water and in the sediment influence the fate of trace metals to a great extent. Adsorption, solubility and complexation characteristics of metals change with their oxidation state. Temporal and spatial redox gradients induce internal cycling of metals (Baccini and Joller, 1981; Balistrieri et al., 1994; Davison, 1993; Friedl et al., 1996; Hamilton-Taylor and Davison, 1995; Sigg et al., 1987, Wehrli et al., 1995). The sediment acts as source or sink, depending on the metal redox characteristics and on the geochemical conditions of the lake. Diffusion through redox boundaries, mixing processes, adsorption and resedimentation may lead to focusing effects with higher concentrations at deeper parts of the basin (Davison, 1993; Francois, 1988; Schaller and Wehrli, 1997; Schaller et al., 1997). Preservation of geochemical signals in the sediment depends on diagenetic 
processes. Formation of iron sulfides (Urban, 1994) and precipitation of phosphates and carbonates (Friedl et al.1996) are the main pathways to record changes in metal concentrations in lake sediments. However, the question remains whether signals of changing redox conditions can be detected and interpreted in high-resolution varve analyses.

In this study, we present metal concentration profiles of $\mathrm{K}, \mathrm{Mg}, \mathrm{La}, \mathrm{Fe}, \mathrm{Mn}, \mathrm{V}$, Cr, As and Mo from the freeze core BA93-C (Lotter et al. 1997a, b) taken in 1993 in Baldeggersee. The special coring technique allowed an exact dating of annually resolved sediment samples between 1885 and 1993. This opens the opportunity to correlate sediment data with limnological time series. Deep-water oxygen conditions are well documented by measurements of profiles at the deepest site since 1949 (Wehrli et al., 1997).

We compare trends of $\mathrm{Fe}, \mathrm{Mn}, \mathrm{V}, \mathrm{Cr}$, As and Mo profiles with long term redox conditions in the hypolimnion in order to select those metals, which react sensitively to changes in benthic oxygen and sulfide. Sharp peaks in the profiles are compared with the annual $\mathrm{O}_{2}$-dynamics to check the sensitivity of metals with respect to wind induced mixing events.

\section{Study site and methods}

\section{Baldeggersee}

Baldeggersee is situated in the prealpine region of central Switzerland, approximately $16 \mathrm{~km}$ north of Lucerne. Since the end of the last century, Baldeggersee had an increased nutrient input. Eutrophication enhanced the sedimentation rate of organic matter, which resulted in anoxic conditions in the hypolimnion (Wehrli et al., 1997; Lotter et al., 1997b; Niessen and Sturm, 1987; Nipkow, 1925). In 1982 an artificial aeration was installed in the lake. The limnological and hydrographic features of the lake, as well as its eutrophication history and the evolution of anoxic conditions in the deep water are discussed in detail by Wehrli et al. (1997).

\section{Sampling and analysis}

In October 1993 two freeze cores were taken in Baldeggersee at its deepest site. The field work and sampling methods are described by Lotter et al. (1997a,b). After the determination of dry weight and particle size distribution, the samples from the core BA93_C (annual resolution) were homogenized in an agate mortar. From the homogenized samples ca. $50 \mathrm{mg}$ were digested with $4 \mathrm{ml} 65 \%$ nitric acid (Merck suprapur) and $1 \mathrm{ml} 30 \%$ hydrogen peroxide (Merck suprapur) in pressurized PTFE bombs in a Milestone "mls 1200 mega" microwave oven. Concentrations of Mg, K, $\mathrm{Mn}$ and Fe were measured with an ICP-OES (Spectro). V, Cr, As, Mo and La were measured by ICP-MS (Perkin-Elmer Sciex). Precision, determined by replicate digestion and measurement, was between $2 \%$ and $7 \%$ for trace metals and between $1 \%$ and $5 \%$ for minor and major elements, except K (10\%). In a former study (Schaller et al., 1997) sediment samples from different strata of Baldeggersee were 
digested with both, the method described above and hydrofluoric acid. Even for the worst case (vanadium) more than $92 \%$ of the particulate fraction was dissolved by the digestion with nitric acid. This uncommonly complete digestion with nitric acid is due to the geological composition of the catchment area (Schaller et al., 1997). One pressure tube was contaminated with Mo and Cr. Concentrations measured in this tube were 3 orders of magnitude higher than the average. These outliers were omitted in the presentation of the results.

\section{Geochemical background}

\section{Benthic redox conditions}

In this section we construct four scenarios of the benthic redox conditions and resulting iron pore-water profiles at the deepest site of Baldeggersee during the last 120 years (Figure 1). This conceptual framework is based on sedimentological and limnological information as well as on recent porewater profiles.

Sediments deposited before 1885 are homogenous and show a light gray color, indicating the presence of bioturbating organisms at an oxic sediment surface (Niessen and Sturm, 1987; Lotter et al., 1997b). Penetration depths of oxygen in such systems are on the order of several mm (Figure 1d) The oxic conditions at the interface allow the formation of an iron oxide film, which has often been observed in sediment cores from mesotrophic Swiss lakes (Ambühl, 1994). The sediment survey in Baldeggersee confirmed that $\mathrm{Fe}, \mathrm{V}$ and $\mathrm{Cr}$ were efficiently trapped at the sediment surface in the mesotrophic lake (Schaller et al., 1997). Sulfide accumulation was an order of magnitude lower in the mesotrophic Baldeggersee than after 1900 (Bott, unpublished results). This observation is consistent with sulfate penetration depths in the range of $10 \mathrm{~cm}$ and very low sulfide concentrations.

Varve counting at the freeze core (Lotter et al., 1997b) confirmed the continuos formation of undisturbed biogenic varves since 1885 in the deep flat plain of Baldeggersee. The preservation of these laminations provides evidence for seasonally anoxic conditions at the sediment-water interface (Figure 1c). Anoxic conditions were restricted at first to the deep flat plain and the lower parts of the slope (Niessen and Sturm, 1987). At the deepest site the increase in organic matter accumulation and the depletion of oxygen and nitrate accelerated the microbial reduction of iron and sulfate. The lower sediment layers, deposited under mesotrophic lake conditions, contained a pool of $\mathrm{Fe}(\mathrm{III})$ and $\mathrm{Mn}$ (IV) which was now reductively mobilized. Accumulation of $\mathrm{Fe}(\mathrm{II})$ and $\mathrm{Mn}$ (II) at the sediment-water interface and in the deep part of the hypolimnion triggered the precipitation of solids such as $\mathrm{FeS}$ and $\mathrm{MnCO}_{3}$.

Since 1940 varve formation has occurred at $40 \mathrm{~m}$ water depth indicating anoxic conditions at the same depth (Niessen and Sturm, 1987). Between the late 1960s and the early 1970s, the phosphorus content of Baldeggersee reached its maximum. As a consequence, meromictic conditions developed in the hypolimnion. Reduced substances such as $\mathrm{Fe}^{2+}, \mathrm{Mn}^{2+}$ and $\mathrm{H}_{2} \mathrm{~S}$ accumulated in the deep water (Wehrli et al., 1997). Sediments of the deep basin were a sink for dissolved sulfide under these conditions (Figure $1 \mathrm{~b}$ ). However, precipitation of FeS within the sediment was limited 
a)

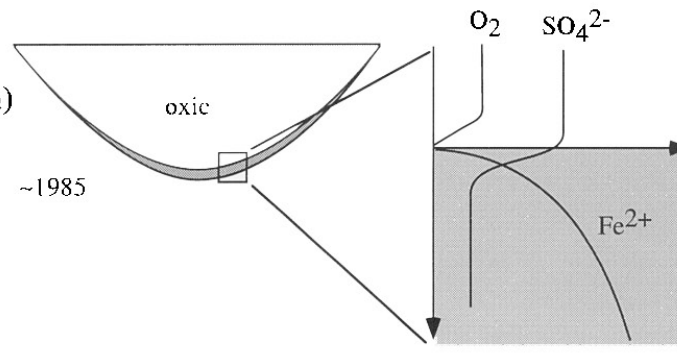

b)

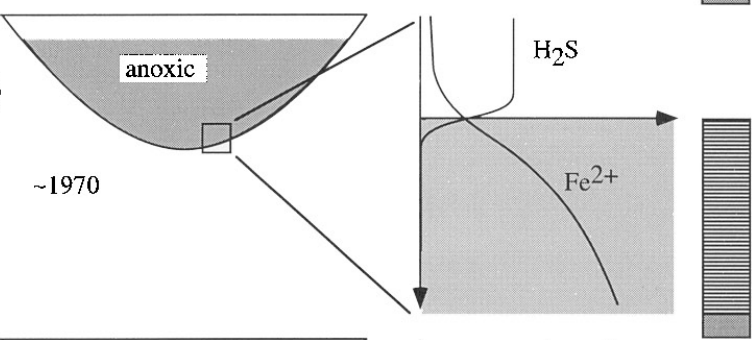

grey marl

c)

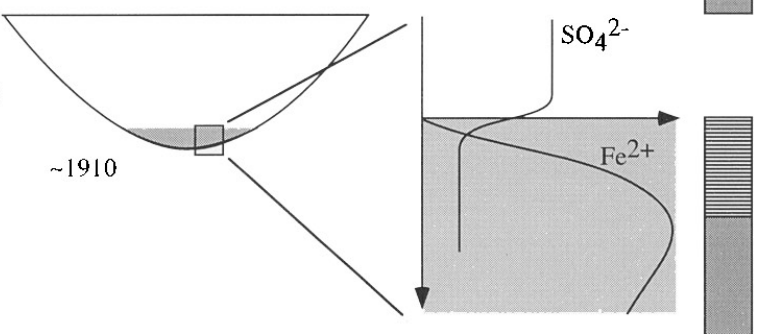

d)
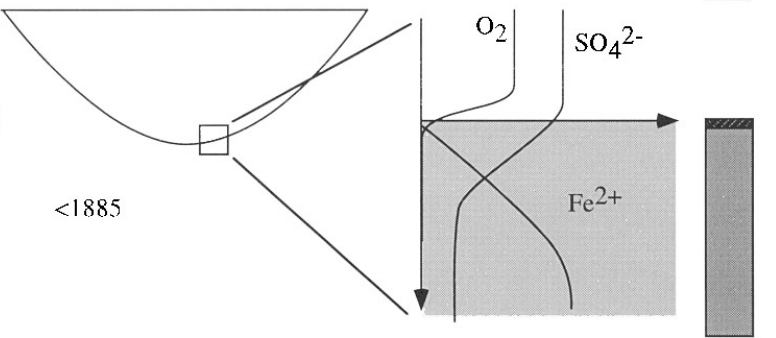

$\mathrm{FeOOH}$

Figure 1. Four scenarios of benthic redox conditions in Baldeggersee. The evolution of hypolimnetic redox conditions (left) is based on the work of Niessen and Sturm (1987). Scenarios for the porewater gradients of sulfur and iron species (center) are based on actual data and results from other anoxic basins (Schaller et al., 1997, Lazzaretti et al., 1992). The sediment stratigraphy (right) is outlined according to the freeze-core observations

by the fact that lower sediment sections were now only a small source of $\mathrm{Fe}(\mathrm{II})$. Settling Fe and Mn oxides were transformed at the sediment water interface.

In 1982 an artificial aeration was installed in the lake. With few exceptions, this method kept the $\mathrm{O}_{2}$-concentration throughout the deep water above $4 \mathrm{mg} \mathrm{l}^{-1}$ (Wehrli et al., 1997). Due to the high oxygen consumption rate the sediment surface 

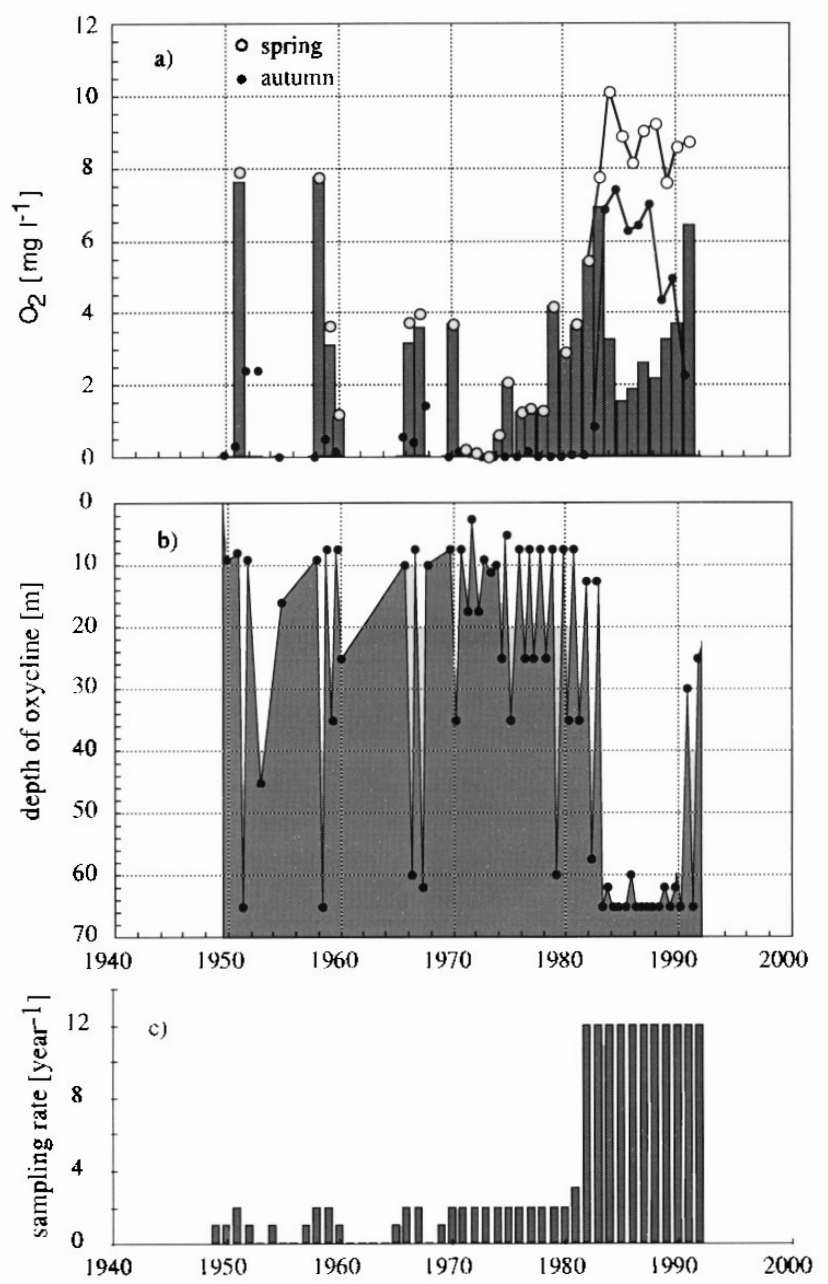

Figure 2. (a) Average oxygen concentrations in the hypolimnion ( $>20 \mathrm{~m}$ ). (b) Approximate position of the oxycline. (c) Number of oxygen profiles per year

is still suboxic (Urban et al., 1997). The pore-water profiles indicate that the deep sediment sections deposited before 1880 are still releasing Fe(II) (Schaller et al., 1997).

\section{Oxygen in the hypolimnion}

The first oxygen profiles were measured in 1949 in Baldeggersee (Figure 2). From 1949 until 1969 only occasional measurements are available. Between 1969 and 1981 oxygen profiles were determined twice a year in February/March and in September/October. Since 1982 the lake is monitored monthly. Figure 2 a presents 
average oxygen concentrations in the hypolimnion (water depth $>20 \mathrm{~m}$ ). For reasons of clarity we only present spring (March) and autumn (November) values for the period 1982-1991. Figure $2 \mathrm{~b}$ shows the approximate position of the oxycline in spring and autumn between 1949 and 1991. Before 1984 average oxygen concentrations in the deep water in autumn were always very low $\left(<2.2 \mathrm{mg} \mathrm{l}^{-1}\right)$ or for most cases below detection limit $\left(<0.1 \mathrm{mg} \mathrm{l}^{-1}\right)$. This indicates stable or seasonally anoxic deep water. Average concentrations in spring show a more dynamic pattern. In 1950 and 1958, the spring values are very high $\left(>7 \mathrm{mg} \mathrm{l}^{-1}\right)$, due to intense mixing during late winter. Between 1959 and 1981 average concentrations were always below $4 \mathrm{mg} \mathrm{l}^{-1}$. During the period 1971-1974 the deep-water was totally anoxic due to meromixis in the hypolimnion. Since 1983 oxygen concentrations were always well above $4 \mathrm{mg} \mathrm{l}^{-1}$. An exception is the autumn value of $1990\left(\sim 2 \mathrm{mg} \mathrm{l}^{-1}\right)$

\section{Sediment stratigraphy and geochemistry}

Lotter et al. (1997b) have established the lithology of the freeze core BA93_C. These authors give a detailed description of the varve sequence between 1885 and 1993. The varve dating is in excellent agreement with ${ }^{137} \mathrm{Cs}$ profiles showing the Chernobyl peak of 1986 and the maximum from nuclear weapons tests of 1963. A total of 16 turbidite layers was identified in the varve sequence. The largest turbidite was deposited in 1956.

Calcite is the dominant mineral in the sediment with a content of $65 \pm 8 \mathrm{wt} \%$. The total organic carbon (TOC) content decreases from $3.1 \mathrm{wt} \%$ in the top section to 2.1 at the bottom, total inorganic carbon (TIC) is rather constant thorough the core with an average of $8 \pm 1 \mathrm{wt} \%$. (Lotter et al., 1997b).

\section{Geochemical characteristics of redox-indicators}

In two previous studies we have analyzed the effect of hypolimnetic oxygen on the internal redox cycles of Mn and Fe in Baldeggersee (Schaller and Wehrli, 1997, Schaller et al. 1997). We have shown that internal cycling of these elements in the water column began with the onset of anoxic conditions at the sediment-water interface. Redox cycling of Mn produces a geochemical focusing effect. Mn is transported from shallower sediments towards the deepest basin of the lake, where strong enrichments are observed. Iron cycling in Baldeggersee enhances the export of iron colloids in the outflow. Therefore the horizontal distribution of iron shows no systematic enrichment in the sediment. However, with the onset of benthic anoxia $\mathrm{V}, \mathrm{Cr}$, As concentrations in the sediment begin to correlate strongly with Fe. This points towards the importance of authigenic iron oxides as carriers for these metals in oxic waters (Belzile and Tessier, 1990; De Vitre et al., 1994; Dzomback and Morel, 1990; Sigg et al, 1987).

In natural aquatic systems $\mathrm{V}$ is found in three oxidation states. Vanadium (V) prevails in oxygenated waters, forming the vanadate oxoanion $\mathrm{H}_{\mathrm{x}} \mathrm{VO}_{4}^{-3+\mathrm{x}}$. Vanadates, like phosphates, have a tendency to form surface complexes with Fe hydroxides. Under moderately reducing conditions the stable form is the vanadyl cation $\mathrm{VO}^{2+}$, which hydrolyses at $\mathrm{pH} 8$ to $\mathrm{VO}(\mathrm{OH})_{\overline{3}}(\mathrm{Baes}$ and Mesmer, 1976). For vanadyl 
a competition between adsorption onto oxide surfaces and complexation with organic ligands is likely to occur (Wehrli and Stumm, 1989). The reduction of V(IV) to V(III) by sulfide is very slow. It is unlikely that this process occurs during early diagenesis in lake sediments (Wanty and Goldhaber, 1992).

Chromium occurs in two oxidation states in aquatic systems. In oxic environments the chromate ion $\mathrm{H}_{\mathrm{x}} \mathrm{CrO}_{4}^{-2+\mathrm{x}}$ is thermodynamically stable (Richard and Bourg, 1991). Compared to vanadate, chromate is more weakly adsorbed to $\mathrm{Fe}$ oxide surfaces. If $\mathrm{Fe}(\mathrm{II})$ or $\mathrm{S}(-\mathrm{II})$ are present $\mathrm{Cr}(\mathrm{VI})$ is very rapidly reduced to $\mathrm{Cr}(\mathrm{III})$. The aqua hydroxy species $\mathrm{Cr}\left(\mathrm{H}_{2} \mathrm{O}\right)_{4}(\mathrm{OH})_{2}^{+}$has a strong tendency for complexation with surface hydroxyl groups (Richard and Bourg, 1991). Johnson et al. (1992) reported evidence for colloidal $\mathrm{Cr}$ (III) in anoxic bottom waters of Greifensee. Mn-oxide is an important oxidizing agent for $\mathrm{Cr}(\mathrm{III})$.

$\mathrm{The} \mathrm{Cr} / \mathrm{V}$ ratio is an indicator which reflects changes in the scavenging efficiency as a function of redox conditions. Under oxic conditions vanadate adsorbs more strongly than chromate, which is more acidic. In anoxic waters, however, chromium (III) forms stronger surface complexes than $\mathrm{VO}^{2+}$.

Arsenate $\left(\mathrm{H}_{\mathrm{x}} \mathrm{AsO}_{4}^{-3+\mathrm{x}}\right)$ is the dominant species of arsenic in oxidized natural waters (Baes and Messmer, 1976; Cullen and Reimer, 1989). Under mildly reducing conditions arsenate is reduced to arsenite $\left(\mathrm{H}_{\mathrm{x}} \mathrm{AsO}_{3}^{-3+x}\right)$. In presence of $\mathrm{S}(-\mathrm{II})$ the solubility of arsenite is controlled by amorphous FeS phases and, depending on the S(-II) concentration, arsenic sulfide. Reduced As(III) is quite stable in oxic environments, due to the relatively slow oxidation kinetics.

Thermodynamic considerations suggest a stable oxidation state of $\mathrm{Mo}(\mathrm{VI})$ in oxic waters (Turner et al., 1981). At neutral $\mathrm{pH} \mathrm{Mo}(\mathrm{VI})$ is strongly hydrolyzed forming the oxoanion $\mathrm{MoO}_{4}^{2-}$ (Baes and Mesmer, 1976). Molybdate is relatively inert in the water column. In contrast to chromate and vanadate, molybdate does not form strong surface complexes with $\mathrm{Fe}$ oxides. Under reducing conditions the stable oxidation state is Mo(IV). Mo is enriched in ocean sediments overlaid by anoxic water columns (Emerson and Huested, 1991) due to a scavenging as $\mathrm{MoS}_{2}$. However, the sulfide concentration in the water-column of most lakes is too low to precipitate pure $\mathrm{MoS}_{2}$. Magyar et al. (1993) postulated three processes for the elimination of Mo from the water column of the seasonally anoxic Greifensee: (1) Coprecipitation of Mo(VI) in mixed $\mathrm{FeS} \cdot \mathrm{MoS}_{3}$ phases, coprecipitation with Mn-oxides and (3) diffusive transport of dissolved Mo(VI) into the sediment.

The variability of calcite concentrations $(65 \pm 8 \mathrm{wt} \%)$ introduces dilution effects on the trace-metal profiles. For this reason we will present profiles of redoxsensitive metals on a carbonate free basis (CFB). Metal concentrations were corrected for dilution effects by using the following equation: $\mathrm{c}_{\mathrm{CFB}}=\mathrm{c} /\left(1-0.01 * \mathrm{CaCO}_{3}\right.$ $[\%])$, where $\mathrm{c}$ is the measured concentration of the metal. $\mathrm{CaCO}_{3}$ values were calculated based on measured total inorganic carbon content (TIC). TIC values correlate well with $\mathrm{Ca}^{2+}$ concentrations, determined by ICP-OES, over the whole freeze core $(r=0.96$, Lotter et al., 1997b).

Metals are widely used in industries and agriculture. Human activities in the catchment area can influence the sedimentation rate of metals in the lake to a great extend. The anthropogenic contribution to Mo, V, Cr, Mn and Fe can probably be neglected in the rural catchment of Baldeggersee. However, a caveat should be 
expressed with respect to As, because this element was widely used in agriculture during the first half of this century.

\section{Results and discussion}

Tracers for allochthonous input: $M g, K, L a$

Figure 3 presents concentration profiles of $\mathrm{CaCO}_{3}$ (Lotter et al., 1997b), $\mathrm{Mg}, \mathrm{K}$ and $\mathrm{La}$. Varves with high $\mathrm{Mg}, \mathrm{K}$ and La content correlate with low $\mathrm{CaCO}_{3}$ concentrations . All of these varves contain turbidite layers (Lotter et al., 1997b).

$\mathrm{Mg}^{2+}$ and $\mathrm{K}^{+}$substitute for $\mathrm{Al}^{3+}$ in the lattice of clay minerals. The ratio between $\mathrm{Mg}^{2+}$ and $\mathrm{K}^{+}$is highly variable between different clays. In the case of Baldeggersee, with a small catchment and low variation of the geological composition, the ratio $\mathrm{Mg} / \mathrm{K}$ can expected to be constant. These metals could therefore be potential tracers for the allochthonous input. However, $\mathrm{Mg}$ is also present in a rather constant proportion of $\mathrm{Ca}: \mathrm{Mg}=27$ in calcites. Potassium on the other hand may be influenced by the intensive use of fertilizers. The strong correlation between $\mathrm{Mg}$ and $\mathrm{K}$ $(\mathrm{r}=0.89)$ indicates a common source. Measurements of $\mathrm{Mg}$ concentrations in freshly precipitated calcite minerals from sediment traps in Baldeggersee showed low values (M. Sturm, personal communication). Therefore, in the case of Baldeggersee, $\mathrm{Mg}$ and $\mathrm{K}$ can be used as qualitative tracers for the allochthonous input. $\mathrm{La}$ is strongly correlated with $\mathrm{Mg}(\mathrm{r}=0.95)$ and offers a further opportunity to trace allochthonous input. Lanthanum is used in cases where $\mathrm{Mg}$ measurements are not available (Schaller et al., 1997).

The profiles of $\mathrm{Mg}, \mathrm{K}$ and $\mathrm{La}$ (Figure 3) indicate that the allochthonous fraction may vary considerably between succeeding varves. Obviously, turbidites can lead to very high contents of allochthonous material in single varves.

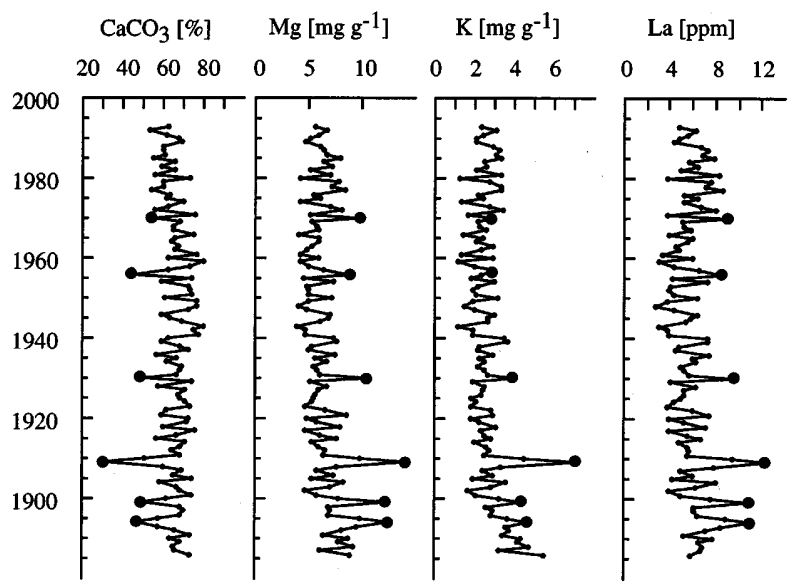

Figure 3. Concentration of $\mathrm{CaCO}_{3}, \mathrm{Mg}, \mathrm{K}$ and $\mathrm{La}$ in the freeze core BA93-C. Large dots indicate varves with turbidite layers (Lotter et al., 1997b) 
High-resolution profiles - Fe, $\mathrm{Mn}, \mathrm{V}, \mathrm{Cr}$, As and $\mathrm{Mo}$

All concentration values presented in this and the following sections are calculated on a carbonate free basis (CFB). Figure 4 shows profiles of the calculated CFB-concentrations for $\mathrm{Fe}, \mathrm{Mn}, \mathrm{V}, \mathrm{Cr}$, As and Mo.

Iron concentrations range between 22.6 and $87.3 \mathrm{mg} \mathrm{g}^{-1}$. The average value of $48 \pm 10 \mathrm{mg} \mathrm{g}^{-1}$ indicates that the varved section of the sediment represented by the samples of the freeze core is enriched in iron if compared to the gray marl deposited before $1885\left(30 \pm 3 \mathrm{mg} \mathrm{g}^{-1}\right.$, Table 1$)$. Within the freeze core the highest Fe values $\left(57 \pm 9 \mathrm{mg} \mathrm{g}^{-1}\right)$ are found between 1886 and ca. 1920. In general Fe concentrations vary considerably between succeeding varves. However, after 1920 until ca. 1960 a gradual decrease of concentrations $\left(0.40 \mathrm{mg} \mathrm{g}^{-1} \mathrm{yr}^{-1}\right)$ can be detected. From 1960 to the early eighties the profile shows no significant trend. The average concentration for this period is $36 \pm 3 \mathrm{mg} \mathrm{g}^{-1}$. Between 1988 and 1991 the profile indicates an Fe-enrichment.
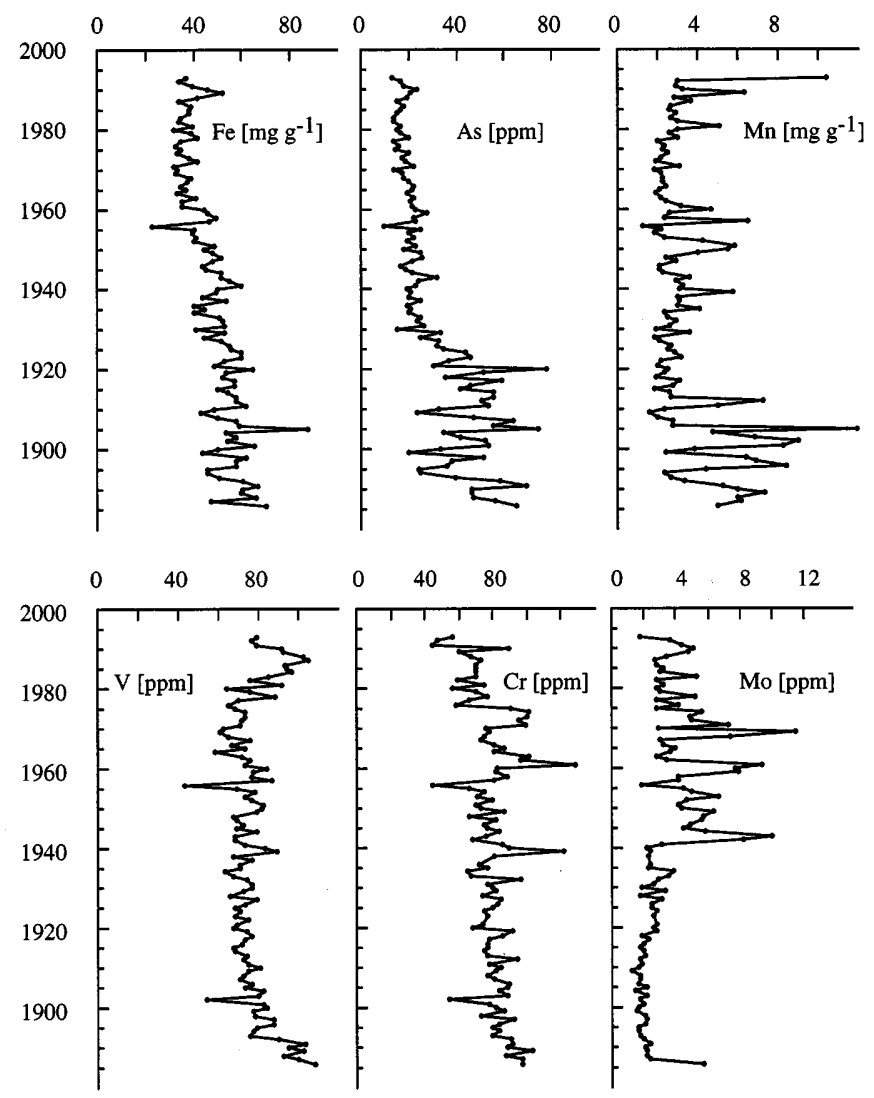

Figure 4. Concentration profiles of $\mathrm{Fe}, \mathrm{As}, \mathrm{Mn}, \mathrm{V}, \mathrm{Cr}$ and $\mathrm{Mo}$ in the freeze core BA93-C. Concentrations are given on a carbonate free basis 
Table 1. Average metal concentrations on a carbonate free basis. Time periods were chosen according to the sedimentological studies of Niessen and Sturm (1987) and Lotter et al. (1997b). Concentrations in sediment strata deposited before 1885 are taken from Schaller et al. (1997).

$\begin{array}{lllllll}\text { Period } & \begin{array}{l}\mathrm{Fe} \\ \mathrm{mg} \mathrm{g}^{-1}\end{array} & \begin{array}{l}\mathrm{Mn} \\ \mathrm{mg} \mathrm{g}^{-1}\end{array} & \begin{array}{l}\mathrm{V} \\ \mathrm{ppm}\end{array} & \begin{array}{l}\mathrm{Cr} \\ \mathrm{ppm}\end{array} & \begin{array}{l}\text { As } \\ \mathrm{ppm}\end{array} & \begin{array}{l}\text { Mo } \\ \mathrm{ppm}\end{array} \\ 1886-1993 & 48 \pm 10 & 3.6 \pm 2 & 77 \pm 11 & 80 \pm 13 & 23 \pm 15 & 4 \pm 2 \\ 1991-1982 & 40 \pm 5 & 3.3 \pm 1 & 92 \pm 12 & 67 \pm 10 & 18 \pm 3 & 4 \pm 1 \\ 1981-1960 & 36 \pm 4 & 2.6 \pm 1 & 72 \pm 8 & 84 \pm 17 & 19 \pm 3 & 5 \pm 2 \\ 1960-1940 & 46 \pm 7 & 3.3 \pm 1 & 74 \pm 9 & 76 \pm 10 & 22 \pm 4 & 5 \pm 2 \\ 1940-1920 & 51 \pm 7 & 2.9 \pm 1 & 73 \pm 6 & 80 \pm 13 & 25 \pm 14 & 3 \pm 1 \\ 1920-1886 & 57 \pm 9 & 4.6 \pm 2 & 80 \pm 11 & 84 \pm 9 & 48 \pm 14 & 2 \pm 1 \\ \text { before } 1885 & 30 \pm 3 & 1 \pm 0.2 & 53 \pm 18 & 64 \pm 18 & 13 \pm 3 & 2 \pm 1\end{array}$

The arsenic profile shows a concentration range between 9.6 and $77.8 \mathrm{ppm}$. From 1886 until ca. 1920 the sediment is significantly enriched in arsenic $(48 \pm 14 \mathrm{ppm})$ with respect to the gray marl deposited before 1885 (13 $\pm 3 \mathrm{ppm}$, Table 1). Between 1920 and 1930, the concentration decreases strongly by ca. 1 ppm $\mathrm{yr}^{-1}$. Since the 1930ies the profile shows no major trend. The average As concentration between 1930 and 1993 is $20 \pm 4$ ppm, indicating a slightly enriched sediment with respect to the gray marl deposited before 1885 (Table 1). Arsenic concentrations are strongly correlated to Fe before $1940(\mathrm{r}=0.81)$ and more weakly after 1940 $(\mathrm{r}=0.66)$.

Manganese concentrations range between 1.2 and $12 \mathrm{mg} \mathrm{g}^{-1}$. Similar to Fe and As biogenic varves are enriched in $\mathrm{Mn}$ if compared to the sediment deposited under mesotrophic lake conditions (Table 1). The profile patterns however, are very different. For Mn periods of strong fluctuations and high concentration values are followed by periods showing a kind of lower "background" concentration. Between 1886 and 1911 high concentration values and variability $\left(5 \pm 2.5 \mathrm{mg} \mathrm{g}^{-1}\right)$ are most expressed. From 1912 until late 1930ies and from the early 1960ies until the late 1970ies two periods with lower average concentrations of $3 \pm 1 \mathrm{mg} \mathrm{g}^{-1}$ and $2 \pm 0.3 \mathrm{mg} \mathrm{g}^{-1}$, respectively, can be detected. Between ca. 1940-1960 and ca. 1980-1993 the profile pattern is marked by several single concentration peaks.

For vanadium and chromium the concentration ranges are 43.7-108.2 ppm and 44.3-128.8 ppm, respectively. The two metals are correlated $(\mathrm{r}=0.76)$ for the period 1886-1940. After 1940 no correlation can be detected. The profiles indicate diverging trends for $\mathrm{Cr}$ and $\mathrm{V}$ after 1940. Chromium shows major enrichments between 1960 and 1980 . V on the other hand is strongly enriched at the top of the core. In the following we will discuss only the ratio $\mathrm{Cr} / \mathrm{V}$.

The molybdenum profile is almost a mirror image of As. Before 1940 Mo concentrations are low $(2 \pm 1 \mathrm{ppm})$ and comparable to the concentrations in the gray marl (Table 1). After 1940 average Mo concentrations increases by a factor of 2.5 (Table 1). The higher concentrations since 1940 are accompanied by a larger variability.

In the following discussion we address first the question of $\mathrm{Fe}$, As and $\mathrm{Mn}$ enrichment in the bottom part of the freeze core. Then we analyze the characteristics of the period with extensive anoxia and meromixis using $\mathrm{Mo}$ and $\mathrm{Cr} / \mathrm{V}$ as 
redox tracers. Finally we look in more detail at possible correlations between the oxygen regime and peaks in the profiles of Mn. The conceptual model in Figure 1 serves as a starting point for the discussion.

\section{The onset of anoxia - Fe, As and Mn}

One of the striking patterns in the profiles are the metal enrichments observed in the period of 1886 - ca. 1920 (Figure 4). The average Fe concentration for this period exceeds the value of the gray marl deposited before 1885 by a factor of 2 (Table 1). The enrichment of As is even stronger (factor 4). The Mn concentrations have a large variability and show the highest values of the investigated period.

Because anoxic conditions were restricted to the deep flat plain (Figure 1) metal enrichment can not be driven by the geochemical focusing effects as described by Schaller and Wehrli (1997). Thus, internal processes in the sediment are the probable cause for the observed increase between 1886 and 1920 .

Iron is often enriched at oxic/anoxic boundaries in the sediment (e.g. Shaw et al., 1990; Thomson et al., 1993). Dissolved $\mathrm{Fe}^{2+}$ diffusing from deeper parts of the sediment is adsorbed on oxyhydroxide surfaces at the redox-boundary. Shaw et al. (1990) showed that enrichment occurs even in suboxic zones. In case of Baldeggersee however, the preserved biogenic varves indicate that anoxic conditions prevailed at the sediment-water interface. Oxidation of dissolved $\mathrm{Fe}^{2+}$ can not contribute to the formation of an enriched layer.

However, preliminary data of acid volatile sulfur (AVS) in the sediment core indicate that the iron enrichment is paralleled by an increase in the concentration of FeS (Bott et al. unpublished results). The pore-water scenarios in Figure 1 illustrate how FeS precipitation could produce an enriched sediment layer at the varve section close to the gray marl: In the early days of deep-water anoxia sulfate reduction was intensified due to the lack of $\mathrm{O}_{2}$ and $\mathrm{NO}_{3}^{-}$. Free sulfide in the pore water diffused into the gray marl and reduced both iron and manganese oxides. The close vicinity of the sulfate reduction zone and reactive $\mathrm{Fe}(\mathrm{III})$ triggered a strong diffusive flux of $\mathrm{Fe}$ (II) from below into the varve section. After two decades 5-10 cm of additional varves had accumulated and the top section of the marl was depleted in $\mathrm{Fe}(\mathrm{III})$. As a consequence the iron flux from below decreased to the low level which is still observed in recent pore-water profiles (Schaller et al. 1997).

This conceptual model explains also the enrichment of As. This element is strongly controlled by Fe-cycling in lakes (Aggett and O'Brian, 1985; Cullen and Reimer, 1989). Arsenate and arsenite have a strong tendency for adsorption on Fe-oxyhydroxides. The dissolved fraction of arsenite is controlled by FeS phases. Intense precipitation of FeS near the sediment-water interface (Figure 1c) would lead to the observed As enrichment.

In the case of manganese the pore-water scenarios in Figure 1 can only explain mobilization but not enrichment. Free sulfide diffusing into the marl section could easily reduce $\mathrm{MnO}_{2}$. However, there is no evidence for $\mathrm{MnS}$ precipitation in these lake sediments. Therefore, we propose that $\mathrm{Mn}^{2+}$ accumulated in the anoxic bottom waters of Baldeggersee from where it precipitated most probably as $\mathrm{MnCO}_{3}$ forming the random pattern in the concentration profile. Rhodochrosite has been detect- 
ed in the sediments of the neighboring Sempachersee using electron microscopy and EXAFS spectroscopy (Friedl et al. 1996).

\section{Meromixis and anoxia: Mo and $\mathrm{Cr} / \mathrm{V}$}

Between 1886 and 1940 Mo concentrations are comparable to the sediment deposited before 1885 (Table 1). After 1940, the accumulation rate of Mo increased by a factor of 2.5. Three mechanisms may lead to the observed Mo enrichment: (1) scavenging by FeS-phases in the water column, (2) scavenging by Mn-oxidation products at the oxycline and (3) diffusive transport of Mo from the water column to the sediment. Since anoxic conditions prevailed in the water column, precipitation of FeS was likely to occur. Oxidation of dissolved $\mathrm{Mn}(\mathrm{II})$ at the redox gradient could promote the adsorption of Mo onto the freshly formed oxide surfaces (Berang and Grill, 1974; Pilipchuk and Volkov, 1974, Sugawara et al., 1961). Mn-oxides would transport Mo to the sediment surface and act, after dissolution, as a Mo source. The observed correlation between Mo and Mn (Schaller et al., 1997) in sediment samples accumulated between 1960 and 1980 supports the hypothesis of scavenging by Mn-oxides. There is some evidence against the third mechanism. Pore water profiles from Baldeggersee show a flux of Mo from the sediment to the water column (Schaller et al., 1997).

In Figure 5 the normalized Mo profile and the ratio $\mathrm{Cr} / \mathrm{V}$ are compared to the time series of oxygen concentrations. The time series of metal concentrations, are based on varve years. A varve year begins in early spring with the first calcite precipitation (Lotter et al., 1997b). To facilitate the comparison with the oxygen time series the metal concentrations in Figure 5 are shifted by one year upwards.

A first period of permanent anoxia is evident around 1960. In the late sixties the average $\mathrm{O}_{2}$ concentration in the hypolimnion reached again $4 \mathrm{mg} \mathrm{l}^{-1}$. The second anoxic period lasted longer (1970-78). Spring oxygen concentrations were always $<2 \mathrm{mg} \mathrm{l}^{-1}$. From 1970 to 1974, the average concentration was even below detection limit. Free sulfide was detected in the water column (Stadelmann, 1984). Both parameters, Mo and $\mathrm{Cr} / \mathrm{V}$ reflect these changes closely. A peak is observed around 1960 followed by a minimum in both profiles. High values are found throughout the seventies. We suggest that sulfide precipitation and formation of Mn oxides in the water column enhanced the scavenging of Mo. Reduction of chromate and vanadate in the water column increased the particle reactivity of $\mathrm{Cr}$ but diminished the scavenging of $\mathrm{V}$. In contrast to $\mathrm{Mo}, \mathrm{Cr} / \mathrm{V}$ values are correlated to average deep water oxygen concentrations in spring (Figure 5). The correlation in the case of $\mathrm{Cr} / \mathrm{V}$ ratios suggests that: (1) processes controlling relative enrichment are fast and (2) the signal in the sediment related to changes in benthic redox conditions is not distorted by early diagenetic processes. On the other hand, early diagenesis seems to influence Mo signals to a great extend.

\section{Oxidation events $-\mathrm{Mn}$}

In this section we discuss whether Mn concentration peaks in the sediment are recording oxidation events in the hypolimnion. Oxygen input by wind induced 

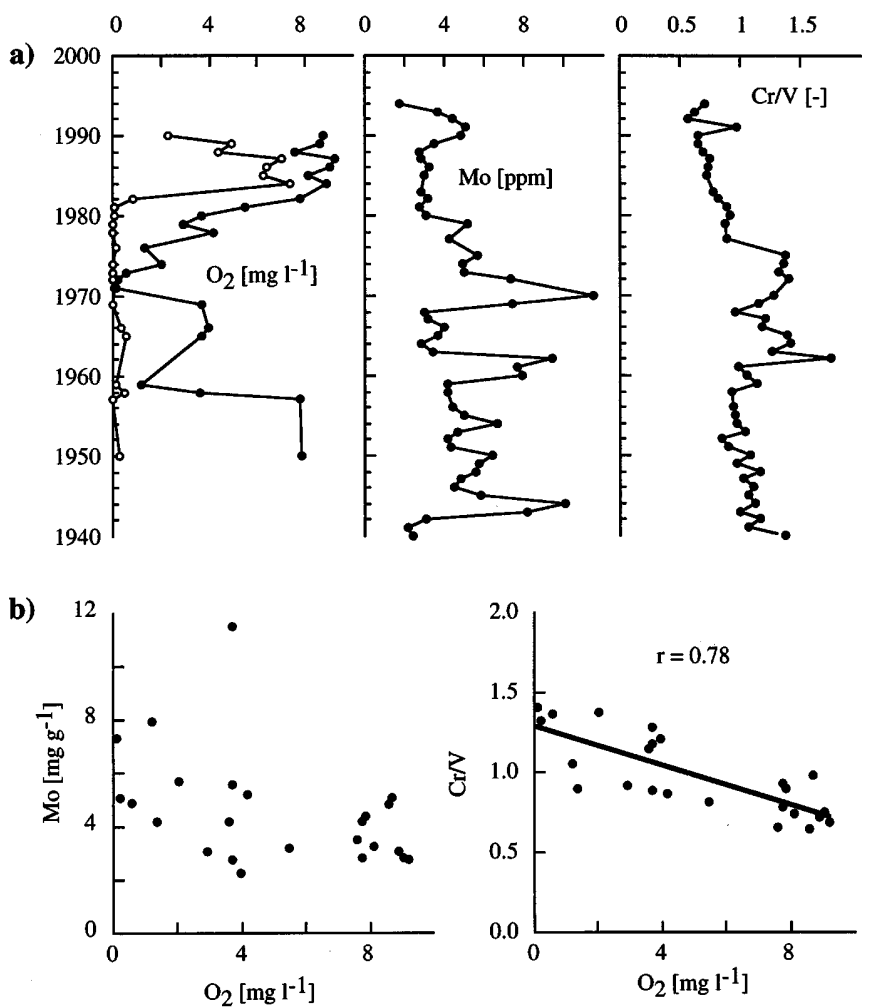

Figure 5. a) Average deep water oxygen concentrations compared with Mo concentrations on a carbonate free basis and Cr/V ratios for the period 1940-1993. b) Mo concentrations and Cr/V ratios plotted against average deep water oxygen concentrations in spring

mixing might produce a particle flux of $\mathrm{MnO}_{2}$, which could be partially preserved in the sediment as $\mathrm{MnCO}_{3}$. The profile of normalized Mn (Figure 6) shows several single concentration peaks between 1940 and 1980. It is compared to the time series of average deep water oxygen concentrations already presented in Figure 2.

In February 1982 oxygen was artificially introduced for a first time in the deep water of Baldeggersee. $\mathrm{Mn}, \mathrm{V}, \mathrm{Cr}$ and to some extend $\mathrm{Fe}$, As and Mo concentrations (Figure 4, 5 and 6) show a single peak in the varve year 1981. Figure 2 indicates a mixing depth of only $35 \mathrm{~m}$ during overturn before the aeration. The sudden presence of oxygen in the lower parts of the hypolimnion probably oxidized dissolved $\mathrm{Mn}^{2+}$ and $\mathrm{Fe}^{2+}$ accumulated in the years before. The intense settling of $\mathrm{FeOOH}$ and $\mathrm{MnO}_{2}$ particles scavenged dissolved $\mathrm{V}, \mathrm{Cr}$, As and Mo. The signal of this event is still recorded in the metal profiles.

The Mn profile shows three other peaks of the same kind in the years 1950, 1958 and 1961 (Figure 6). The first two peaks correlate with strong seasonal variation of oxygen conditions in the deep water. During autumn of these years the deep water 

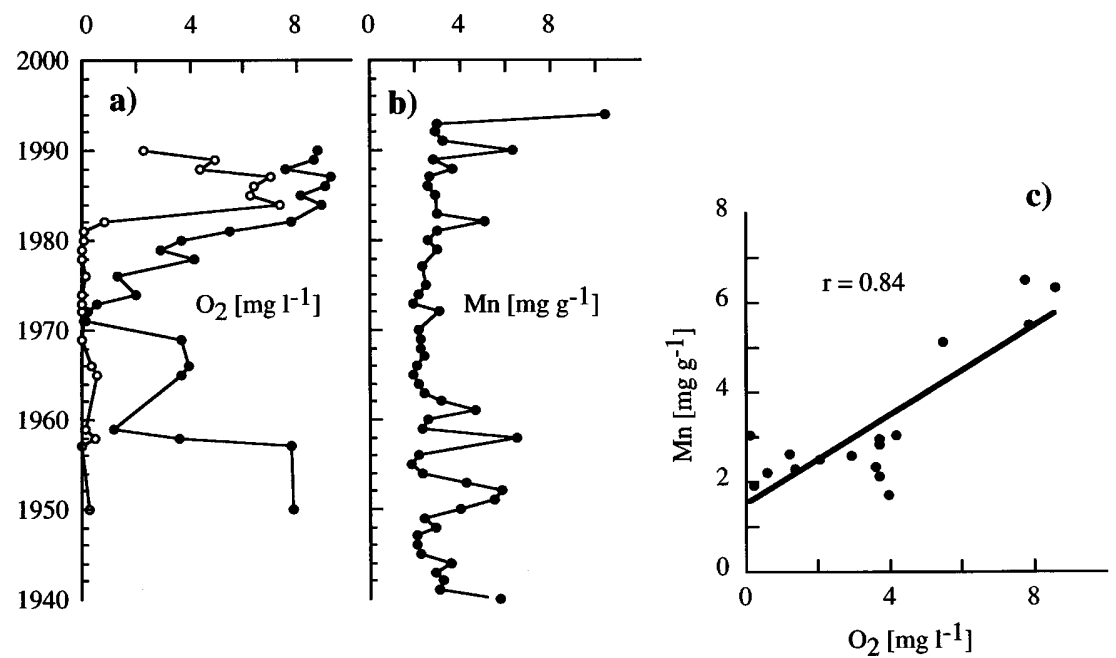

Figure 6. Average deep water oxygen concentrations (a) compared with Mn concentrations on a carbonate free basis for the period 1940-1993 (b). Mn concentrations plotted against average deep water oxygen concentrations in spring (c)

of Baldeggersee was always anoxic. Mn diffusing from the sediment accumulated in the anoxic hypolimnion. During spring overturn intense mixing increased average oxygen concentrations from $<0.1 \mathrm{mg} \mathrm{l}^{-1}$ to $7 \mathrm{mg} \mathrm{l}^{-1}$. Dissolved Mn was oxidized and precipitated, increasing the sedimentation rate of Mn for this specific year. We suggest that intense reductive dissolution at the sediment-water interface mobilized $\mathrm{Mn}^{2+}$ in excess of the solubility product of $\mathrm{MnCO}_{3}$. Precipitation of rhodochrosite may thus record a signal of the oxidation event in the anoxic sediment.

Although Mn values are correlated to average deep water oxygen concentrations in spring (Figure 6), the distribution of the data suggests two distinct groups: (1) constant low Mn values at low oxygen concentrations indicating incomplete mixing and (2) high Mn concentrations at high average $\mathrm{O}_{2}$ values indicating strong winter storms with complete mixing.

It is tempting to speculate that even the Mn maxima at the bottom of the freeze core (1886-1911) were produced by mixing and oxidation events. Rather high $\mathrm{Mn}^{2+}$ concentrations could have accumulated in the deep flat plane of Baldeggersee at the onset of eutrophication. Oxygen transport to the bottom requires strong winter storms, which do not occur every year. This possible correlation of Mn maxima with meteorological data is the subject of further studies.

\section{Conclusions}

We have analyzed the annually laminated sediments deposited between 1886 and 1993 at the deepest site in Baldeggersee. The freeze-core technique allowed the direct comparison of metal concentrations in the sediment with limnological time 
series. The following indicators show potential for paleolimnological reconstruction in Baldeggersee and in similar systems:

1) Magnesium, potassium and lanthanum can be used as qualitative tracers for allochthonous input.

2) The Mn profile exhibits several sharp peaks which can be attributed to oxidation events. Wind induced mixing transports $\mathrm{O}_{2}$ into the anoxic hypolimnion oxidizing dissolved $\mathrm{Mn}^{2+}$. Part of the precipitated $\mathrm{MnO}_{2}$ accumulates in the sediment in the form of $\mathrm{Mn}(\mathrm{II})$ minerals such as $\mathrm{MnCO}_{3}$. The relation of Mn concentration peaks to intense mixing events opens a possibility to trace climatic signals of strong winter storms.

3) Mo concentrations and the $\mathrm{Cr} / \mathrm{V}$ ratio are sensitive tracers for permanent anoxia with accumulation of $\mathrm{H}_{2} \mathrm{~S}$ and $\mathrm{Fe}^{2+}$ in the deep water.

4) The transition from oxic to anoxic conditions in the bottom water produced an enrichment layer with high concentrations of Fe and As and diagnostic peaks of Mn.

\section{ACKNOWLEDGMENTS}

We would like to thank A. Lotter, C. Stengel, M. Sturm and A. Zwyssig for sample preparation, sediment stratigraphy and lithology data. Many thanks to G. Friedl, J. Terranes, D. Livingstone, M. Mengis, M. Sturm, H. Weissert and A. Wüest for intense discussions and corrections of the manuscript. This study was supported by the Swiss National Science Foundation through the National Research Program 31 (NFP-31) grant 4031-33147.

\section{REFERENCES}

Aggett, J. and G. A. O'Brien, 1985. Detailed model for the mobility of arsenic in lacustrine sediments based on measurements in Lake Ohakuri. Environ. Sci. Technol. 19:231-238.

Ambühl, H., 1994. Die Feinstruktur jüngster Sedimente von Seen verschiedenen Trophiegrades und von Seen mit technischer Sanierung. Limnologische Berichte Donau 2:101-126.

Baccini, P. and T. Joller, 1981. Transport processes of copper and zinc in a highly eutrophic and meromictic lake. Schweiz. Z. Hydrol. 43(1):176-199.

Baes, C. I. and R. E. Mesmer, 1976. The hydrolysis of cations. New York, John Wiley.

Balistrieri, L. S., J. W. Murray and B. Paul, 1994. The geochemical cycling of trace metals in a biogenic meromictic lake. Geochim. Cosmochim. Acta 58(19):3993-4008.

Belzile, N. and A. Tessier, 1990. Interactions between arsenic and iron oxyhydroxides in lacustrine sediments. Geochim. Cosmochim. Acta 54:103-109.

Berang, P. G. and E. V. Grill, 1974. The effect of manganese oxide scavenging on molybdenum in Saanich Inlet, Britisch Columbia. Marine Chemistry 2:125-148.

Cullen, W. R. and K. J. Reimer, 1989. Arsenic speciation in the environment. Chem. Rev. 89: $713-764$.

Davison, W., 1993. Iron and Manganese in lakes. Earth-Science Reviews 34:119-163.

De Vitre, R. R., B. Sulzberger and J. Buffle, 1994. Transformations of iron at redox boundaries. In: Chemical and biological regulations of aquatic systems (Eds. J. Buffle and R. R. De Vitre) pp: 91-138. Boca Raton, Lewis Publishers.

Dzombak, D. A. and F. M. M. Morel, 1990. Surface complexation modeling. New York, Wiley.

Emerson, S. R. and S. S. Huested, 1991. Ocean anoxia and the concentrations of molybdenum and vanadium in seawater. Marine Chemistry 34:177-196.

François, R., 1988. A Study on the regulation of the concentrations of some trace metals (Rb, Sr, $\mathrm{Zn}, \mathrm{Pb}, \mathrm{Cu}, \mathrm{V}, \mathrm{Cr}, \mathrm{Ni}, \mathrm{Mn}$ and $\mathrm{Mo}$ ) in Saanich Inlet sediments, British Columbia, Canada. Marine Geology 83:285-308. 
Friedl, G., B. Wehrli and A. Manceau, 1996. The role of solids in the cycling of manganese in eutrophic lakes - New insights from EXAFS-spectroscopy. Geochim. Cosmochim. Acta 61: $275-290$.

Hamilton-Taylor, J. and W. Davison, 1995. Redox-Driven Cycling of Trace Elements in Lakes. In: Physics and Chemistry in Lakes Eds. A. Lerman, D. M. Imboden and J. Gat, pp: 217-258. New York, Springer.

Johnson, C. A., L. Sigg and U. Lindauer, 1992. The chromium cycle in a seasonally anoxic lake. Limnol. Oceanogr. 37(2):315-321.

Lazzaretti, M. A., K. W. Hanselmann, H. Brandl, D. Span, R. Bachofen, 1992. The role of sediments in the phosphorus cycle in Lake Lugano. II. Seasonal and spatial variability of microbiological processes at the sediment-water interface. Aquatic Sciences 54:285-299.

Lotter, A. F., I. Renberg, H. Hansen, R. Stöckli, M. Sturm, 1997a. A remote controlled freeze corer for sampling unconsolidated surface sediments. Aquatic Sciences 59:295-303.

Lotter, A. F., M. Sturm, J. Teranes, B. Wehrli, 1997b. Varve formation since 1885 and highresolution varve analyses in hypertrophic Baldeggersee (Switzerland). Aquatic Sciences 59:304-325.

Magyar, B., H. C. Moor and L. Sigg, 1993. Vertical distribution and transport of molybdenum in a lake with seasonal anoxic hypolimnion. Limnol. Oceanogr. 38:521-531.

Niessen, F. and M. Sturm, 1987. The sediments of lake Baldegg (Switzerland) - Sedimentary enviromement and developement of eutrophication for the last 100 years. Arch. Hydrobiol. 108: $365-383$.

Nipkow, F., 1925. Über das Verhalten der Skelette planktischer Kieselalgen in geschichtetem Tiefenschlamm des Zürich- und Baldeggersees. Schweiz. Z. Hydrol. 4:71-120.

Pilipchuck, M. F. and I. I. Volkov, 1974. Behavior of molybdenum in processes of sediment formation and diagenesis. In: The Black Sea: Geology, chemistry and biology (Eds. E. T. Degens and Ross, D. A.) pp: 542-552. Am. Assoc. Petrol. Geol. Mem.

Richard, F. C. and A. C. M. Bourg, 1991. Aqueous geochemistry of chromium: a review. Water Res. $25: 807-816$.

Schaller, T. and B. Wehrli, 1997. Geochemical focusing of manganese in lake sediments- An indicator of deep water oxygen conditions. Aquatic Geochemistry 2(4):359-378.

Schaller, T., H. C. Moor and B. Wehrli, 1997. Reconstruction of the iron cycle from the horizontal distribution of metals in the sediment of Baldeggersee. Aquatic Sciences 59:325-344.

Shaw, T. J., J. M. Gieskes and R. A. Jahnke, 1990. Early diagenesis in differing depositional environments: The response of transition metals in pore water. Geochim. Cosmochim. Acta 54: $1233-1246$.

Sigg, L., M. Sturm and D. Kistler, 1987. Vertical transport of heavy metals by settling particles in Lake Zürich. Limnol. Oceanogr. 32(1):112-130.

Stadelmann, P., 1984. Die Zustandsentwicklung des Baldeggersees (1900-1980) und die Auswirkung von seeinternen Massnnahmen. Wasser, Energie, Luft 76:85-95.

Sugawara, K., S. Okabe and M. Tanaka, 1961. Geochemistry of molybdenum in natural waters (II). J. Earth Science Ngoya Univ. 9:114-128.

Thomson, J., N. C. Higgs, I. W. Croudace, S. Colley and D. J. Hydes, 1993. Redox zonation of elements at an oxic/postoxic boundary in deep-sea sediments. Geochim. Cosmochim. Acta 57: $579-595$.

Thomson, J., N. C. Higgs, T. R. S. Wilson, I. W. Croudace, G. J. DeLange, P. J. M. Van Santvoort, 1995. Redistribution and geochemical behaviour of redox-sensitive elements around S1m the most recent eastern Mediterranean sapropel. Geochim. Cosmochim. Acta 59:3487-3501.

Turner, D. R., M. Whitfield and A. G. Dickson, 1981. The equilibrium speciation of dissolved components in freshwater and seawater at $25^{\circ} \mathrm{C}$ and $1 \mathrm{~atm}$ pressure. Geochim. Cosmochim. Acta $45: 855-881$.

Urban, N. R., C. Dinkel, B. Wehrli, 1997. Solute transfer across the sediment surface of a eutrophic lake: I. Porewater profiles from dialysis samplers. Aquat. Sci. 59:1-25.

Wanty, R. B. and M. B. Goldhaber, 1992. Thermodynamics and kinetics of reactions involving vanadium in natural systems: Accumulation of vanadium in sedimentary rocks. Geochim. Cosmochim. Acta 56:1471-1483.

Wehrli, B. and W. Stumm, 1989. Vanadyl in natural waters: Adsorption and hydrolysis promote oxygenation. Geochim. Cosmochim. Acta 53:69-77. 
Wehrli, B., G. Friedl and A. Manceau., 1995. Reaction Rates and products of manganese oxidation at the sediment-water interface. In: C. P. Huang, C. R. O'Melia and J. J. Morgan (Eds.) “Aquatic Chemistry, Interfacial and Interspecies Processes". ACS Advances in Chemistry Series 244, Washington DC. 111-138.

Wehrli, B., A. F. Lotter, T. Schaller, M. Sturm, 1997. The high-resolution varve project in Baldeggersee (Switzerland); limnological trends (1950-1993). Aquatic Sciences 59:285-294.

Received 8 January 1997;

revised manuscript accepted 6 October 1997. 